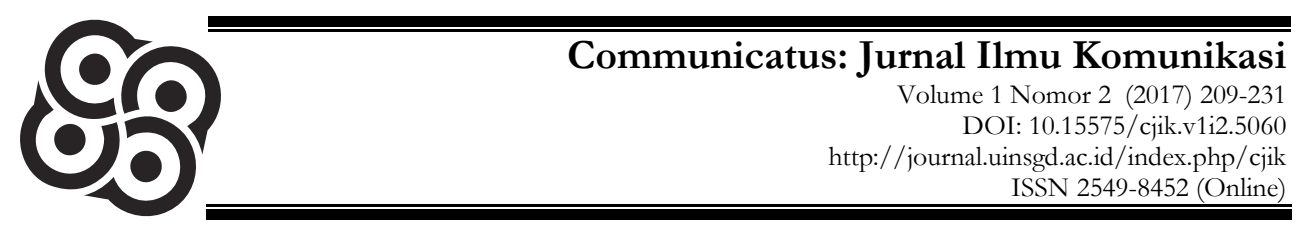

\title{
Pola Komunikasi Perempuan Pesisir: Studi Etnografi Komunikasi
}

\author{
Yayah Nurhidayah* \\ IAIN Syeikh Nurdjati Cirebon \\ * email: yayabnurb@yahoo.com.au
}

\begin{abstract}
Communication is bound by culture. As culture differs from one another, the communication practices and behaviors of individuals cared for in different cultures will have different communication methods. The coastal women's community is a sub-culture of the Cirebon community, besides having unique and distinctive characteristics, they have an important role in helping to increase the economic income of the fishermen's family. The involvement of coastal women in the public sphere is increasingly expanding their interactions and social relations, both with people inside and with outsiders. The implication is that coastal women are faced with various challenges in interactions that require communication competencies. Lack of understanding of the culture of the participants involved in the interaction will give rise to social conflict: such as quarrels, hostilities, misunderstandings and prejudices.
\end{abstract}

Keywords : Patterns of Communication, Women, Coastal.

\begin{abstract}
ABSTRAK
Komunikasi itu terikat oleh budaya. Sebagaimana budaya berbeda antara satu dengan lainnya, maka praktek dan perilaku komunikasi individu-individu yang diasuh dalam budaya berbeda akan memiliki cara-cara komunikasi yang berbeda. Komunitas perempuan pesisir merupakan sub-kultur dari masyarakat Cirebon, selain memiliki karakteristik yang unik dan khas, mereka memiliki peran penting dalam membantu menambah penghasilan ekonomi keluarga nelayan. Keterlibatan perempuan pesisir di ranah publik, makin memperluas interaksi dan relasi sosialnya, baik dengan orang dalam maupun dengan orang luar. Implikasinya, perempuan pesisir dihadapkan pada berbagai tantangan dalam interaksi yang membutuhkan kompetensi komunikasi. Kurangnya pemahaman tentang budaya dari peserta yang terlibat dalam interaksi, akan melahirkan konflik sosial: seperti terjadi pertengkaran, permusuhan, salah paham dan prasangka.
\end{abstract}

Kata Kunci: Pola Komunikasi, Perempuan, Pesisir.

\section{PENDAHULUAN}

Komunikasi adalah salah satu dari kegiatan sehari-hari yang benar-benar terhubung dengan semua aspek kehidupan manusia. Setiap aspek kehidupan manusia dipengaruhi oleh komunikasi. "Komunikasi berhubungan dengan 
Yayah Nurhidayah

perilaku manusia dan kepuasan terpenuhinya kebutuhan berinteraksi dengan manusia-manusia lainnya. Hampir setiap orang membutuhkan hubungan sosial dengan orang-orang lainnya dan kebutuhan ini terpenuhi melalui pertukaran pesan yang berfungsi sebagai jembatan untuk mempersatukan manusia-manusia yang tanpa berkomunikasi akan terisolasi”.

Dalam praktek sehari-hari komunikasi antar manusia seringkali mengalami hambatan karena adanya perbedaan diantara pelaku komunikasi. Salah satu hambatan dalam komunikasi adalah adanya perbedaan budaya. Setiap komunikasi kita dengan orang lain mengandung potensi komunikasi antar budaya, bahwa kita selalu berbeda budaya dengan orang lain, seberapa kecilpun perbedaan itu (Mulyana, 1996:vi), komunikasi memiliki hubungan timbal balik. Budaya menjadi bagian dari perilaku komunikasi dan sebaliknya komunikasi menentukan, memelihara, mengembangkan atau mewariskan budaya. "Culture is Communication, Communication is Culture" (Hall dalam Mulyana, 1996:vi).

Melalui budaya orang-orang belajar komunikasi. Cara-cara kita berkomunikasi, keadaan-keadaan komunikasi kita, bahasa dan gaya bahasa yang digunakan dan perilaku non-verbal, semua itu terutama merupakan respon terhadap dan fungsi budaya. Sebagaimana budaya berbeda antara satu dengan lainnya, maka praktek dan perilaku komunikasi individu-individu yang diasuh dalam budaya-budaya tertentu akan berbeda pula. Kesulitan berkomunikasi dengan orang lain, khususnya yang berbeda budaya, bukan saja merupakan kesulitan memahami bahasa mereka, melainkan juga sisitem nilai dan bahasa nonverbal mereka. Bahasa non verbal dimanapun lebih dominan dari bahasa verbal. Oleh karena itu, komunikasi yang tidak peka terhadap sistem nilai yang dianut suatu komunitas budaya dapat menimbulkan perselisihan (Hall dalam Mulyana, 1996:vi).

Masyarakat pesisir adalah masyarakat yang tinggal dan melakukan aktifitas sosial ekonomi yang berkaitan dengan sumber daya wilayah pesisir dan lautan. Dari segi penghasilan, masyarakat pesisir yang mata pencahariannya didominasi oleh pekerjaan sebagai nelayan yang bergelut dengan laut untuk mendapatkan penghasilan, pendapatan yang mereka inginkan tidak bisa dikontrol. Nelayan menghadapi sumber daya yang bersifat open acces dan beresiko tinggi. Oleh karena itu, Sebagian besar penduduk yang bermukim di pesisir dan hidup dari pengelolaan sumber daya kelautan/perikanan umumnya tergolong miskin.

Meskipun begitu, kawasan pesisir, selain memiliki potensi sumber daya alam, juga memiliki potensi sosial yang cukup besar. Salah satu potensi sosial yang dimiliki adalah kaum perempuan, khususnya istri nelayan. Kedudukan atau peran perempuan pesisir, istri nelayan pada masyarakat pesisir dianggap sangat penting, karena kaum perempuan pesisir atau istri nelayan mengambil peran yang besar pada kegiatan sosial-ekonomi di darat, sementara laki-laki bekerja di 
Pola Komunikasi Perempuan Pesisir: Studi Etnografi Komunikasi

laut untuk mencari nafkah dengan menangkap ikan. Kedua, perempuan pesisir selalu terlibat dalam kegiatan publik, yaitu mencari nafkah untuk mengantisipasi jika suami mereka tidak memperoleh penghasilan. Kegiatan melaut merupakan kegiatan spekulatif dan terikat oleh musim. Oleh karena itu, nelayan yang melaut belum tentu memperoleh penghasilan. Ketiga, perempuan sebagai salah satu pilar penyangga kebutuhan hidup rumah tangga. Dalam menghadapi kerentanan ekonomi dan kemiskinan masyarakat nelayan, perempuan merupakan pihak yang paling bertanggungjawab dan terbebani untuk mengatasi dan menjaga kelangsungan hidup rumah tangga. Sebagaimana dikemukakan (Kusnadi, 2006:2).

Perempuan yang bekerja dan memiliki posisi ekonomi menjadi faktor yang menentukan dalam berhubungan dengan laki-laki, baik pada bidang aktifitas di dalam keluarga maupun masyarakat. Dengan kata lain, keterlibatan perempuan dalam aktifitas ekonomi di ranah publik memberi kontribusi terhadap perubahan status sosial perempuan. Selain itu, pekerjaan suatu komunitas akan mempengaruhi cara-cara mereka berinteraksi dan berkomunikasi.

Keterlibatan perempuan di ranah publik ini, makin memperluasnya interaksi dan relasi sosial perempuan baik dengan orang dalam maupun dengan orang luar. Interaksi sosial perempuan yang makin komplek, menyebabkan perempuan berhadapan dengan berbagai tantangan dalam situasi interaksi yang mengharuskan ia memiliki kompetensi komunikasi. Kurangnya pemahaman tentang budaya dari masing-masing individu yang terlibat dalam interaksi, akan menyebabkan terjadinya konflik sosial seperti: pertengkaran, permusuhan, salah paham dan prasangka.

Dalam praktek sehari-hari komunikasi antar manusia seringkali mengalami hambatan karena adanya perbedaan diantara pelaku komunikasi. Salah satu hambatan dalam komunikasi adalah adanya perbedaan budaya. Melalui budaya orang-orang belajar komunikasi. Cara-cara kita berkomunikasi, keadaan-keadaan komunikasi kita, bahasa dan gaya bahasa yang digunakan dan perilaku non-verbal, semua itu terutama merupakan respon terhadap dan fungsi budaya. Sebagaimana budaya berbeda antara satu dengan lainnya, maka praktek dan perilaku komunikasi individu-individu yang diasuh dalam budaya-budaya tertentu akan berbeda pula.

Kesulitan berkomunikasi dengan orang lain, khususnya yang berbeda budaya, bukan saja merupakan kesulitan memahami bahasa mereka, melainkan juga sisitem nilai dan bahasa nonverbal mereka. Bahasa non verbal dimanapun lebih dominan dari bahasa verbal. Oleh karena itu, komunikasi yang tidak peka terhadap sistem nilai yang dianut suatu komunitas budaya dapat menimbulkan perselisihan. 
Yayah Nurhidayah

Sebelum mengkaji lebih lanjut, perlu kiranya ada tinjauan penelitian sejenis yang telah dilakukan sebelumnya, baik itu dari aspek perempuan pesisir maupun dari aspek komunikasi pesisir. Perempuan pesisir menjadi kajian yang banyak dilakukan sebelumnya diantaranya adalah kajian tentang; Kajian Perempuan Pesisir dalam Mendukung Konservasi Sumber Daya Pesisir di Kabupaten Raja Ampat (Handayani, 2011), Kategori dan Fungsi Sosial Ungkapan Kepercayaan Masyarakat Larang Pantang Calon Pengantin Perempuan di Nagari Barung-Barung Balantai Kecamatan Koto Xi Tarusan Kabupaten Pesisir Selatan (Sefridanita, 2012).

Tugas dan Wewenang Badan Pemberdayaan Masyarakat, Perempuan dan Keluarga Berencana (BPMPKB) dalam Meningkatkan Kesejahteraan Nelayan di Wilayah Pesisir Kota Tegal (Saraswati, 2012), Partisipasi Perempuan Nelayan dalam Konservasi Wilayah Pesisir di Kecamatan Meureubo Kabupaten Aceh Barat (Fithria dkk, 2012).

Bantuan PNPM Mandiri dalam Bidang Simpan Pinjam Bagi Perempuan Di Nagari Sungai Liku Kecamatan Ranah Pesisir Kabupaten Pesisir Selatan (Nengsih, 2013), Fataloza Nur Razak : Profil Perempuan Penerima Bantuan Program Nasional Pemberdayaan Masyarakat (Pnpm) Mandiri di Nagari Lalang Panjang Kecamatan Air Pura Kabupaten Pesisir Selatan (Ningsih dkk, 2014), Perempuan Madura Pesisir Meretas Budaya Mode Produksi Patriarkat (Mulyadi, 2011), Peran Emansipatoris Perempuan Pesisir (Istri Nelayan Sebagai Ujung Tombak Ekonomi) (Wahyudi, 2011) dan Analisis Kesiapsiagaan dan Kerentanan Perempuan di Wilayah Pesisir dalam Menghadapi Bencana Gempa dan Tsunami di Banda Aceh (Deviani, 2013).

Penelitian tentang pola komunikasi Perempuan pesisir memiliki signifikansi dalam rangka menjembatani perbedaan budaya tersebut. Sebab masyarakat pesisir merupakan suatu komunitas budaya yang memiliki karakteristik tertentu yang berbeda dengan masyarakat lain. Masyarakat pesisir merupakan masyarakat yang tinggal dan melakukan aktifitas sosial ekonomi yang terkait dengan sumberdaya wilayah pesisir dan lautan.

Adapaun penelitian yang mengkaji tentang perempuan pesisir diantaranya adalah, Analisis Interaksi Simbolik yang Membentuk Pola Komunikasi Dinamis Pada Komunitas Pesisir Kabupaten Jember (Fajar, 2011), Peran Komunikasi Pembangunan dalam Pemberdayaan Masyarakat Pesisir (Amanah, 2010). Hubungan Komunikasi Interpersonal Remaja Putri Bersama Orang Tua Dengan Perilaku Seks (Studi terhadap Remaja Putri di Nagari Lunang Satu Kecamatan Lunang Kabupaten Pesisir Selatan) (Parwati, 2014), Society Communication Patterns In The Era Of Information Technology Case Study Coastal Village, Besuki District, District Situbondo (Trisnani. (2016), Komunikasi Antarpribadi Warga Belajar Di Pkbm Sari Kecamatan Rumbai Pesisir Kota Pekanbaru (Riza dkk, 2016), Intensitas Komunikasi Pembelajaran 
dalam Mengukur Keberhasilan Program Pendidikan Paket B di Desa-Desa Pesisir Kecamatan Belang (Ruata dkk, 2014), Family Communication Strategy to Improve Gender Equality for Girls in Coastal of South Sulawesi Province (Strategi Komunikasi Keluarga untuk Meningkatkan Kesetaraan Gender bagi Anak Perempuan di Kawasan Pesisir Provinsi Sulawesi Selatan) (Fatimah, 2016) dan Pengaruh Kepemimpinan, Komunikasi dan Lingkungan Kerjaterhadap Kinerja Pegawai Kantor Dinas Pendidikan dan Kebudayaan Kabupaten Pesisir Selatan (Dharma, 2016).Kajian penelitian sebelumnya banyak yang membahas dari aspek perempuan pesisir maupun komunikasi masyarakat pesisir, sedangkan penelitian ini lebih terfokus pada aspek pola komunikasi ditinjau dari studi etnografi komunikasi.

Masyarakat pesisir yang mata pencahariannya didominasi oleh pekerjaan sebagai nelayan yang bergelut dengan laut untuk mendapatkan penghasilan, pendapatan yang mereka inginkan tidak bisa dikontrol. Nelayan menghadapi sumberdaya yang bersifat open acces dan beresiko tinggi. Oleh karena itu, Sebagian besar penduduk yang bermukim di pesisir dan hidup dari pengelolaan sumber daya kelautan/perikanan umumnya tergolong miskin. Meskipun begitu, kawasan pesisir, selain memiliki potensi sumber daya alam, juga memiliki potensi sosial yang cukup besar. Salah satu potensi sosial adalah kaum perempuan, khususnya istri nelayan. Kedudukan atau peran perempuan pesisir, istri nelayan pada masyarakat pesisir sangat penting.

Pertama, Kaum perempuan pesisir atau istri nelayan mengambil peran yang besar pada kegiatan sosial-ekonomi di darat, sementara laki-laki bekerja di laut untuk mencari nafkah dengan menangkap ikan. Kedua, perempuan pesisir selalu terlibat dalam kegiatan publik, yaitu mencari nafkah untuk mengantisipasi jika suami mereka tidak memperoleh penghasilan. Kegiatan melaut merupakan kegiatan spekulatif dan terikat oleh musim. Oleh karena itu, nelayan yang melaut belum tentu memperoleh penghasilan. Ketiga, perempuan sebagai salah satu pilar penyangga kebutuhan hidup rumah tangga. Dalam menghadapi kerentanan ekonomi dan kemiskinan masyarakat nelayan, perempuan merupakan pihak yang paling bertanggungjawab dan terbebani untuk mengatasi dan menjaga kelangsungan hidup rumah tangga.

Perempuan yang bekerja dan memiliki posisi ekonomi menjadi faktor yang menentukan dalam berhubungan dengan laki-laki, baik pada bidang aktifitas di dalam keluarga maupun masyarakat. Dengan kata lain, keterlibatan perempuan dalam aktifitas ekonomi di ranah publik memberi kontribusi terhadap perubahan status sosial perempuan. Selain itu, pekerjaan suatu komunitas akan mempengaruhi cara-cara mereka berinteraksi dan berkomunikasi.

Keterlibatan perempuan di ranah publik ini, makin memperluasnya interaksi dan relasi sosial perempuan baik dengan orang dalam maupun dengan 
Yayah Nurhidayah

orang luar. Interaksi sosial perempuan yang makin komplek, menyebabkan perempuan berhadapan dengan berbagai tantangan dalam situasi interaksi yang mengharuskan ia memiliki kompetensi komunikasi. Kurangnya pemahaman tentang budaya dari masing-masing individu yang terlibat dalam interaksi, akan menyebabkan terjadinya konflik sosial seperti: pertengkaran, permusuhan, salah paham dan prasangka.

Berdasarkan permasalahan di atas, penelitian ini akan mengamati polapola Komunikasi perempuan pesisir, agar cara-cara mereka berkomunikasi baik dengan orang dalam maupun dengan orang luar, dan ciri-ciri perilaku komunikasi mereka dapat dipetakan.

\section{HASIL DAN PEMBAHASAN}

\section{Gambaran Umum Desa Mertasinga}

Wilayah pesisir merupakan pertemuan antara wilayah daratan dan lautan. Kedua wilayah itu memiliki karakteristik yang berbeda. Wilayah pesisir secara umum mengandalkan mata pencaharaian pokok masyarakatnya pada pemanfaatan sumber daya kelautan. Sedangkan wilayah daratan memiliki keragaman dalam mata pencaharian.

Desa Mertasinga adalah salah satu wilayah pesisir yang ada di Kabupaten Cirebon, dimana masyarakat secara mayoritas mengandalkan mata pencaharian terutama pada potensi kelautan. Desa Mertasinga secara geografis memiliki batas wilayah sebelah utara berbatasan dengan desa Purwawinangun, sebelah selatan berbatasan dengan desa Grogol, sebelah timur berbatasan dengan laut Jawa dan sebelah barat berbatasan dengan desa Sirnabaya.

Posisi Desa Mertasinga yang lebih dekat dengan wilayah kota, menjadikan desa ini dalam beberapa hal memiliki kesamaan karakteristik dengan masyarakat perkotaan, meskipun sebenarnya masyarakat desa Mertasinga masih termasuk dalam kategori pedesaan. Misalnya, dilihat dari data statistik, tingkat pendidikan masyarakat di desa Mertasinga mayoritas lulus sekolah menengah (SLTA/ sed erajat). Luas wilayahnya sekitar 252.200 ha. 60.000 ha. diperuntukkan untuk usaha perikanan, 33.000 ha. untuk pemukiman, 25.000 ha. untuk persawahan dan sisanya untuk fasilitas umum. Penduduk desa Mertasinga diperkirakan berjumlah 6.681 orang terdiri dari 3.234 orang perempuan dan 3.447 orang laki-laki. Agama yang dianut masyarakat di desa Mertasinga mayoritas beragama Islam.

Pekerjaan sehari-hari para nelayan di desa Mertasinga sebagai nelayan penangkap ikan dan terutama Rajungan. Sementara, isteri nelayan atau kaum perempuan sebagian bekerja sebagai bakul Rajungan, pedagang warung, penjual makanan dan ibu rumah tangga. Pekerjaan sebagai bakul rajungan atau pengepul ikan itu dilakukan setiap hari dari jam 9.00 sampai jam 15.00, setelah suami mereka datang dari melaut. Namun, jadwal seperti itu tidak selamanya sama tergantung dari kedatangan suami mereka dari melaut dan perolehan tangkapan 
Pola Komunikasi Perempuan Pesisir: Studi Etnografi Komunikasi

ikan dan rajungan. Pada musim-musim tertentu, para nelayan mengalami kesulitan untuk memperoleh hasil tangkapan, maka para suami (nelayan) ini dibawa oleh juragan-juragan mereka untuk mencari tangkapan ikan ke Jakarta atau daerah lain. Uang hasil tangkapan ikan selama berada di perantauan itu dikirimkan oleh sang juragan kepada istri-istri mereka.

Di desa pesisir yang bergantung pada sumber daya perikanan, aktifitas ekonomi sangat fluktuatif sesuai dengan rotasi musim ikan. Musim ikan tidak berlangsung sepanjang tahun. Dalam masa satu tahun, musim ikan hanya berlangsung beberapa bulan. Produktifitas yang bersifat musiman ini sangat berpengaruh terhadap aktifitas perempuan di desa pesisir.

Aktifitas perempuan pesisir yang biasanya bertugas sebagai pengepul, tengkulak dan penjual ikanpun terhenti. Mereka beralih pekerjaan sebagai ibu rumah tangga biasa dan ada sebagian yang berusaha mencari pekerjaan lain sebagai buruh dan pedagang. Dalam mengatasi persoalan ekonomi rumah tangga, isteri-isteri nelayan mengambil peran yang strategis. Selagi memungkinkan dari segi keterampilan dan pengadaan modal, ister-isteri nelayan terlibat dalam kegiatan ekonomi di sector informal. Kaum perempuan tidak hanya menjadi penguasa riil di sector ekonomi rumah tangga, tetapi juga penguasa kegiatan ekonomi di sector informal.

Selain itu, isteri-isteri nelayan ini sangat kreatif menciptakan beragam pranata social ekonomi. Misalnya melalui arisan, tabungan harian, dan usaha simpan-pinjam. Namun, ketika tiba-tiba mereka dihadapkan pada kesulitan ekonomi, sedangkan uang dari sang juragan belum diberikan, biasanya mereka meminjam uang terlebih dahulu kepada para investor keliling (mereka menyebutnya tukang kredit).

Aktifitas perempuan di kampung nelayan mulai sibuk pada jam-jam 9.0015.00, mereka menimbang, mencatat hasil tangkapan rajungan yang diperoleh kaum laki-laki, lalu dikumpulkan. Setelah terkumpul banyak, kemudian dijual kepada juragan (boss) untuk di eksport. Sepulang dari menjual/ mengirimkan rajungan kepada bosnya, mereka kembali ke tempat pengepul rajungan untuk membayarkan kembali uang hasil penjualan itu kepada para nelayan, yang sebelumnya telah menyetorkan hasil tangkapan. Selanjutnya, kegiatan kaum lakilaki diteruskan dengan kegiatan membersihkan jaring dari sisa-sisa ikan kecil dan sampah yang masih menempel dibantu oleh seluruh anggota keluarga seperti: anak. Istri, cucu dan menantu bekerja sama. Di tempat lain, terlihat sebagian perempuan bekerja sebagai pengupas kulit rajungan. Begitulah aktifitas seharihari kaum perempuan di kampung pesisir Mertasinga.

Bila diamati, peran kaum perempuan di kampung nelayan, mereka bisa tampil sebagai bos (juragan), dimana mereka bisa duduk-duduk santai sambil menunggu kaum laki-laki menyetorkan hasil tangkapan dari melaut, memeriksa penimbangan, mencatat dan membayarkan uang. Bahkan, beberapa dari mereka 
Yayah Nurhidayah

terlihat duduk-duduk santai sambil merokok, bersenda gurau dan menikmati makanan yang dijajakan pedagang keliling. Penampilan perempuan pesisir ini terlihat bersih dan mereka juga mengenakan perhiasan emas. Sementara, penampilan kaum laki-laki, terlihat agak kotor, penuh keringat, basah dan tampak kelelahan, namun mereka tetap melanjutkan pekerjaan berikutnya yaitu membersihkan jaring kejer. Tak jarang, hal itu dilakukan sepulang melaut jam 10.00 wib hingga menjelang jam 15.00. Menjelang tegah malam sekitar jam 22.00 WIB. Kaum laki-laki sudah harus siap-siap pergi ke laut untuk menebar jaring di lautan dan menungguinya sampai pagi hari untuk memanen hasil tangkapan.

Bila dilihat dari relasi social laki-laki dan perempuan di kampung nelayan, terlihat ada hubungan yang setara dan egaliter. Laut adalah ranah kaum laki-laki, sementara di darat adalah ranah kaum perempuan. Tugas kaum laki-laki mencari ikan dan bertanggungjawab untuk memperoleh hasil tangkapan sebanyakbanyaknya. Ketika di darat, kaum perempuan bertanggungjawab untuk memasarkan, mengolah dan mengelola keuangan hasil tangkapan.

\section{Peristiwa Komunikasi Pada Komunitas Perempuan Pesisir Mertasinga}

Untuk mendeskripsikan peristiwa komunikasi pada komunitas perempuan pesisir, peneliti pertama-tama menentukan situasi komunikasi atau tempat terjadinya komunikasi. Berdasarkan observasi pendahuluan, peneliti memperoleh informasi bahwa aktifitas perempuan di kampung nelayan lebih banyak dihabiskan di tempat pengepul ikan/rajungan yang tidak jauh dari lingkungan rumah mereka. Oleh karena itu, peneliti menentukan tempat pengepul rajungan, sebagai setting atau tempat peristiwa komunikasi itu akan diamati.

Di tempat pengepul rajungan itulah mereka biasa berinteraksi dengan sesama kaum perempuan, anak-anak, suami, dan dengan anggota keluarga maupun orang-orang luar (asing) seperti: pedagang, tukang kredit, tamu dan lain-lain. Peneliti melakukan beberapa kali observasi partisipan dengan mengikuti kegiatan mereka di tempat pengepul rajungan mulai dari jam 9.00 sd jam 15.00. Dari hasil observasi di lapangan, ditemukan berbagai peristiwa komunikasi yang terjadi secara berulang.

\section{Setting atau Konteks Terjadinya Peristiwa Komunikasi.}

Setting atau tempat terjadinya komunikasi sangat menentukan pola komunikasi. Dalam penelitian ini setting atau tempat terjadinya peristiwa komunikasi adalah tempat pengepul rajungan (di pekarangan rumah bu Sarwi). Karakteristik fisik atau ruangan tempat terjadinya peristiwa komunikasi para perempuan nelayan ini sangat sederhana dan apa adanya. Yaitu sebuah pekarangan di depan rumahrumah mereka. Tidak perlu ruangan tertutup atau tempat-tempat jualan semacam 
lapak sebagaimana pasar pada umumnya. Pekarangan rumah itulah satu-satunya tempat mereka berkumpul menunggu para nelayan menjual ikan/ rajungan hasil tangkapan mereka. Meskipun tidak ada ruangan khusus yang dirancang sedemikian rupa, mereka dapat dengan leluasa berkomunikasi dengan sesamanya.

Berdasarkan setting-nya, tempat terjadinya komunikasi diantara perempuan nelayan itu hanyalah tempat yang sangat sederhana, jauh dari kesan tempat pertemuan atau tempat transaksi dan jual beli (pasar). Padahal, hasil tangkapan ikan atau rajungan itu memiliki nilai ekonomis tinggi dan menjadi bahan komoditas ekspor. Sarana lain yang menandai tempat penjualan ikan itu adalah alat penimbangan ikan, ember-ember dan drum-drum besar yang terbuat dari plastik. Selama melakukan aktifitas, mereka duduk di jongkok yang terbuat dari kayu. Meskipun begitu, tetap dapat terlihat terdapat perbedaan kategori sosial diantara mereka yang dapat disaksikan dari penampilan atau pakaian.

Pakaian yang mereka kenakan dalam aktifitas penjualan adalah pakaian sehari-hari, rapih, bersih dan bebas. Penampilan yang terkesan bersih dan rapih ini menjadi penanda khusus yang membedakan mereka dengan para perempuan nelayan pada umumnya, yang biasanya kumal, kotor dan bau amis. Begitupun dengan perhiasan yang mereka pakai. Rata-rata mereka mengenakan perhiasan emas berupa kalung, cincin dan gelang. Beberapa orang dari mereka terlihat mengenakan perhiasan yang lebih banyak dan mencolok dari yang lain. Mereka adalah para juragan atau bos. Adapula yang memiliki kebiasaan merokok dalam melakukan aktifitas di tempat kerjanya. Sepintas, tidak ada kesan kemiskinan di kalangan mereka, dan tidak tampak ada aturan-aturan yang terlalu kaku yang membatasi pergaulan mereka.

Berdasarkan hasil pengamatan di lapangan ditemukan bahwa perempuan pesisir ini memiliki komunikasi yang khas, ketika mereka berada di tempat ini. Misalnya, adanya kecenderungan pola komunikasi perempuan lebih dominan dibandingkan dengan laki-laki. Perempuan lebih banyak menggunakan bahasa verbal, sementara laki-laki lebih banyak menggunakan bahasa non-verbal. Hal ini dapat ditunjukkan dengan perilaku perempuan yang terus menerus berbicara, ketika mereka menjalankan pekerjaan di tempat pengepul rajungan, mereka juga bebas bersenda gurau, tertawa, saling mengejek, dan tak jarang guyon mereka bernuansa seks (vulgar).

Sementara, aktifitas yang dilakukan laki-laki di tempat itu, dimulai dari kedatangan mereka dari melaut, duduk-duduk beristirahat, menyerahkan hasil tangkapan dan kembali ke pantai untuk mengambil kembali ikan-ikan yang belum selesai diangkut untuk disetorkan lagi, setelah itu mereka mengambil jaring untuk dibersihkan dibantu oleh anggota keluarganya. Laki-laki bekerja membersihkan jaring dengan tekun, tidak banyak berbicara hanya sesekali merespon pembicaraan dan sesekali tersenyum.

Situasi komunikasi di tempat pengepul rajungan ini, sangat berbeda 
Yayah Nurhidayah

dengan situasi komunikasi perempuan, ketika berada di rumah. Di rumah mereka cenderung lebih pasif dalam aktifitas komunikasi. Laki-laki justru lebih dominan. Berdasarkan pengamatan, dapat diidentifikasi beberapa peristiwa komunikasi berikut:

Pertama, konsep tempat bagi komunitas perempun di pesisir Mertasinga ini sangat penting. Tempat menentukan kode berbicara dan jenis pembicaraan apa yang akan ditampilkan. Perempuan pesisir memiliki dua model komunikasi. Komunikasi horizontal, simetris, yang ditampilkan ketika mereka berada di tempat kerja (tempat pengepul ikan) dalam interkasi dengan rekan-rekan kerja, sedangkan komunikasi vertikal ditampilkan ketika mereka berada di rumah dalam interaksi dengan suami dan anak-anak. Kedua, tempat menjadi arena ekspresi diri dan penentu hubungan interpersonal di kalangan perempuan. Di tempat kerja, komunitas perempuan bebas mengekspresikan diri masing-masing tanpa ada tekanan ataupun batas-batas hirarkis dan aturan-aturan etika yang kaku. Sementara, di rumah kaum perempuan ini harus menampilkan sosok yang sesuai dengan peran mereka sebagai isteri dan ibu. Sebagai isteri, dituntut mampu berkomunikasi dan berinteraksi dengan suami secara santun, sebagai ibu, perempuan dituntut untuk selalu memberi contoh dan teladan kepada anak-anak.

Tujuan komunikasi diantara penjual dan pembeli rajungan adalah komunikasi transaksional. Dimana pihak-pihak yang terlibat dalam komunikasi saling melakukan transaksi: pemilik ikan menyerahkan hasil tangkapannya kepada pengepul untuk dijual dan pengepul menerima, menimbang dan mencatat atau membayar secara langsung. Aktifitas komunikasi diantara mereka merupakan peristiwa yang terus berulang setiap hari-hari, sehingga simbol-simbol dan kodekode percakapan telah dimaknai secara sama, tanpa harus menggunakan komunikasi verbal, melalui komunikasi non-verbal pertukaran simbol dan pesanpesan komunikasi diantara mereka mudah dipahami.

Tujuan komunikasi di kalangan perempuan nelayan memiliki beragam tujuan antara lain:

transaksional: terjadi ketika komunitas perempuan melakukan komunikasi di dalam aktifitas penjualan (penerimaan dan penyerahan) hasil tangkapan dari para nelayan yang datag ke tempat itu.

Informatif: terjadi ketika komunitas perempuan pesisir saling berbagi informasi tentang keadaan musim, kondisi pantai, tentang keadaan keluarga masing-masing dan sebagainya.

Kesenangan: mengamati aktifitas keseharian mereka yang terlihat ceria, penuh canda dan tawa memperlihatkan bahwa komunikasi bagi mereka tidak melulu bersifat transaksional, informatif, tetapi juga arena untuk bersenangsenang, berkumpul dan terlibat pembicaraan dengan sesama kaum perempuan, tanpa disibukkan dengan pekerjaan rumah tangga mengasuh anak, memasak, melayani suami, bahkan mereka bisa menunjukkan eksistensi diri masing-masing. 
Hiburan: komunikasi bagi perempuan pesisir ini memiliki fungsi hiburan, melepaskan ketegangan, mengisi waktu luang setelah pagi-pagi mereka disibukkan dengan aktifitas domestik. Komunikasi juga berfungsi untuk memelihara hubungan. Di tempat ini mereka berbagi pengalaman, saling membantu dan saling berbagi perhatian.

Topik pembicaraan diantara komunitas perempuan di kampung nelayan meliputi: pembicaraan tentang hasil tangkapan, uang, anak-anak, pasar, jaring dan makanan. Misalnya, Sarwi menanyakan kepada setiap orang yang datang dari melaut: akeh beli Rajungan ne?, begitu juga pertanyaan yang diajukan oleh perempuan kepada teman-teman sesama pengepul, misalnya, dina kiyen oli pirang kilo?.

Sebagai suatu komunitas, perempuan nelayan yang bekerja ini juga banyak bertukar informasi tentang anak-anak mereka, tentang kondisi keuangan di masing-masing keluarga, tentang masalah-masalah yang berkaitan dengan pekerjaan sebagai nelayan, misalnya jaring yang rusak, dicuri dan lainnya. Tak ketinggalam mereka juga berbagi pengalaman tentang suka-duka, termasuk gossip dan hal-hal pribadi.

Peserta komunikasi dalam peristiwa komunikasi di kampung nelayan, meliputi: pengepul, penjual, anak-anak, suami, pedagang makanan, tukang kredit dan tukang mainan anak-anak. Dilihat dari usia, peserta komunikasi di tempat itu mayoritas berusia dewasa, sudah menikah, namun ada anak-anak balita yang mereka bawa serta sambil bekerja di tempat itu. Sedangkan dilihat dari status social ekonomi, para peserta yang terlibat adalah: Juragan kapal, bakul dan para penjual (pemasok).

Di kalangan perempuan nelayan ini, hubungan sosialnya relative intensif dan egaliter. Sehingga perbedaan status social diantara mereka cenderung tidak berfungsi. Perbedaan status social tidak menjadi penghalang dalam komunikasi dan berinteraksi diantara mereka. Kehidupan mereka sangat gotong royong dan saling tolong menolong. Hal ini ditunjukkan dengan tanggung jawab yang diberikan oleh juragan kepada para nelayan. Misalnya, ketika para nelayan tidak bisa melaut di daerah tangkapan mereka, karena paceklik atau cuaca tidak mendukung, para juragan mengajak mereka untuk melaut ke tempat lain, dan penghasilan selama di perantauan dikirimkan kepada keluarganya oleh sang juragan atau keluarga mereka diberi pinjaman sementara.

Hierarki kewenangan diantara partisipan komunikasi, tidak terlalu mencolok. Sebab posisi juragan dan nelayan buruh atau nelayan biasa di kampung nelayan Mertasinga terlihat sederajat. Juragan pemilik kapal atau perahu bekerja sama melaut dengan nelayan buruh dan bersama-sama menebar jaring, membersihkannya serta mengangkut hasil tangkapan ke daratan secara bersama-sama. Adanya pola komunikasi simetris diantara juragan dan nelayan menggambarkan adanya relasi kuasa yang seimbang. Begitupun dengan hak dan 
Yayah Nurhidayah

kewajiban yang mereka miliki dan mereka penuhi. Juragan dan nelayan samasama memiliki hak untuk melaut dan mencari ikan sebanyak-banyaknya. Juragan dan nelayan memiliki kewajiban untuk mengikuti kesepakatan dan aturan yang dibuat oleh kelompok serta memiliki kewajian untuk membayar iuran, retribusi dan biaya akomodasi lainnya.

Posisi perempuan (pengepul) ikan dalam hierarki social di kampung nelayan mengikuti posisi suami, ketika suaminya menjadi juragan, maka secara otomatis isteri nelayan memiliki posisi sebagai juragan pula. Peran yang dimainkan perempuan yang menduduki posisi juragan ini, sedikit berbeda dengan anggota komunitas nelayan biasa. Dalam komunitas mereka, juragan dianggap memiliki otoritas sebagai pemimpin atau bos. Sebagai bos, mereka biasanya memiliki anak buah (pembantu). Pembantu-pembantu inilah yang mengendalikan pekerjaan menimbang, mencatat dan Menyetorkan hasil tangkapan kepada agen. Juragan perempuan ini bertindak sebagai juru bayar dan bendahara. Meskipun begitu, hubungan social diantara perempuan sang juragan dengan pengepul ikan lainnya tetap harmonis dan saling menghormati. Tidak ada perbedaan dalam kaidah interaksi maupun dalam komunikasi diantara mereka.

Bentuk Pesan: penulis akan menganalisis tentang; isi pesan, bentuk, sekuen dan kekuatan pesan dalam situasi komunikasi. Berdasarkan pengamatan dan kesempatan berinteraksi dengan perempuan pesisir, di lapangan ditemukan bahwa komunitas perempuan secara umum cenderung menggunakan pesanpesan verbal (bahasa lisan). Sedangkan laki-laki cenderung menggunakan pesan non-verbal. Hal ini terjadi karena kondisi masing-masing berbeda. Perempuan sebagai penerima, dan pembeli hasil tangkapan mereka lebih energik, sementara kaum laki-laki kurang energik karena kelelahan sehabis melaut.

Isi pesan: Isi pesan komunikasi yang mereka sampaikan mudah dipahami. Artinya, cenderung tidak mengalami banyak kendala dalam pemahaman diantara peserta komunikasi. Hal ini, karena mereka menggunakan bahasa jawa yang sama, logat dan intonasi yang sama. Juga ada persamaan dalam budaya dan nilainilai yang mereka anut. Hambatan dalam memahami pesan komunikasi terjadi ketika mereka berkomunikasi dengan orang asing. Misalnya, karena sebagian dari mereka tidak mahir berbicara dalam bahasa Indonesia, terutama di kalangan orang tua dan mereka juga tidak mengerti bahasa jawa halus.

Pesan apa yang memiliki signifikansi: dari hasil pengamatan di lapangan ada beberapa pesan yang memiliki signifikansi di kalangan perempuan pesisir. Mereka cenderung antusias dan merespon baik kedatangan orang luar (asing), terutama kalangan pejabat dan pengusaha. Mereka sangat menghargai tamu (orang asing), Hal ini, karena mereka selalu menganggap kedatanga orang luar, terutama pejabat atau pengusaha identik dengan akan adanya bantuan, sumbangan dan modal.

Jadi, di kalangan perempuan pesisir bahwa pesan yang memiliki 
Pola Komunikasi Perempuan Pesisir: Studi Etnografi Komunikasi signifikansi adalah yang berkaitan dengan pemenuhan kebutuhan hidup mereka sehari-hari, misalnya: uang, peralatan, subsidi, bantuan pendidikan dan kesehatan. Selain itu, ada beberapa pesan yang menjadi perhatian perempuan di kampung nelayan yang berkaitan dengan dunia kerja mereka antara lain: Jaring, Musim, Kredit dan perahu.

Bahasa yang dipergunakan dalam komunikasi mereka dengan sesama teman pengepul, suami dan anak-anak adalah bahasa jawa kasar. Sedangkan bahasa yang dipergunakan untuk berkomunikasi dengan orang luar adalah bahasa Indonesia. Aksen bahasa Jawa yang dipakai dalam komunitas ini bahasa Jawa dengan aksen suara "O" di ahir kata. Sedangkan aturan-aturan berbicara dalam komunitas perempuan nelayan desa Mertasinga misalnya:

Berkomunikasi dengan keluarga, teman menggunakan bahasa jawa biasa.

Perempuan banyak berbicara menggunakan bahasa verbal (komunikasi lisan)

Perempuan pesisir tidak banyak menggunakan kontak mata secara langsung ketika berbicara dengan laki-laki

Bahasa yang digunakan dalam komunikasi kepada orang yang status sosialnya lebih tinggi dari mereka tidak berbeda dengan bahasa yang dipergunakan sehari-hari dengan keluarga dan dengan teman. Bahasa yang berbeda hanya akan digunakan kepada orang luar saja.

Urutan Tindakan komunikasi, dalam peristiwa komunikasi perempuan pesisir, ditemukan adanya overlap dalam pembicaraan. Artinya, masing-masing peserta komunikasi berbicara tidak berurutan dan menunggu giliran, melainkan saling berebut mendahului, bahkan beberapa orang peserta sering nada suaranya lebih tinggi dari yang lain, sehingga kesannya ribut, berisik dan seperti saling ingin menguasai. Peristiwa komunikasi seperti ini dapat menggambarkan bahwa pola komunikasi mereka adalah model Persamaan. (Equality).

Dalam pola ini, tiap individu membagi kesempatan komunikasi secara merata dan seimbang, peran yang dimainkan tiap orang dalam situasi komunikasi adalah sama. Tiap orang dianggap sederajat dan setara kemampuannya, bebas mengemukakan ide-ide, opini, dan kepercayaan. Komunikasi yang terjadi berjalan dengan jujur, terbuka, langsung, dan bebas dari pemisahan kekuasaan yang terjadi pada hubungan interpersonal lainnya. Dalam pola ini tidak ada pemimpin dan pengikut, pemberi pendapat dan pencari pendapat, tiap orang memainkan peran yang sama. Komunikasi memperdalam pengenalan satu sama lain, melalui intensitas, kedalaman dan frekuensi pengenalan diri masing-masing, serta tingkah laku non-verbal seperti sentuhan dan kontak mata yang seimbang jumlahnya. Tiap orang memiliki hak yang sama dalam pengambilan keputusan, baik yang sederhana seperti, siapa yang lebih dahulu melakukan penjualan, maupun yang penting seperti siapa yang ditetapkan sebagai juragan, sebagai pengepul dan sebagainya. 
Yayah Nurhidayah

Konflik yang terjadi tidak dianggap sebagai ancaman. Masalah diamati dan dianalisa. Perbedaan pendapat tidak dilihat sebagai salah satu kurang dari yang lain, tetapi sebagai benturan yang tak terhindarkan dari ide-ide atau perbedaan nilai dan persepsi yang merupakan bagian dari hubungan jangka panjang.

Kaidah interaksi, di komunitas perempuan nelayan ini hampir tidak ada batasan interaksi, tidak ada hierarki social yang membatasi interaksi. Mereka berinteraksi secara setara dengan suami, anak dan dengan juragan. Bahkan isteriisteri nelayan terlihat lebih dominan dalam pengaturan masalah keuangan dan dalam pengambilan keputusan untuk menggunakan dan membelanjakan uang. Di dalam tradisi mereka suami tidak pernah menguasai uang. Isteri yang mengurus hasil tangkapan ikan suami dan memegang uang hasil penjualannya, Tugas suami melaut. Segala kebutuhan suami dan keluarga, istri yang mengendalikan. Walaupun istri yang memegang uang, ia tidak akan menghambur-hamburkannya untuk hal-hal yang tidak bermanfaat, karena bisa merusak rumah tangga. Suami isteri saling percaya.

Norma Interpretasi. Di komunitas perempuan desa Mertasinga sebenarnya tidak banyak aturan yang mengekang kehidupan mereka. Mereka terbiasa dengan hal-hal yang mudah. Bahkan tabu atau larangan-larangan budaya juga saat ini sudah dianggap hal biasa. Misalnya, larangan tidak boleh melaut pada hari-hari tertentu, itu tidak ada lagi, yang membatasi aturan tidak boleh melaut hanya kondisi alam saja. Tradisi upacara seperti Nadran, nilai-nilai sakralitasnya sudah mulai berkurang dalam persepsi masyarakat nelayan saat ini, mereka memaknai Nadran hanya sebagai pesta rakyat biasa, yang berlangsung di laut bagi kalangan nelayan. Pelaksanaan upacara Nadran adalah tugas laki-laki, perempuan tidak ikut dalam upacara itu. Laki-laki juga yang menyiapkan segala perlengkapan untuk upacara tersebut.

Dalam tradisi mereka tidak ada tabu yang membatasi mereka berbicara. Misalnya, kepada siapa, kapan dan dimana mereka boleh dan tidak boleh berbicara. Bagi komunitas perempuan pesisir Mertasinga, mereka bebas berbicara kepada siapa saja, kapan saja dan dimana saja. Bahkan hasil pengamatan di lapangan justru masyarakat pesisir sangat ramah terhadap orang luar yang datang ke kampung mereka apapun tujuannya.

\section{Komponen Komunikasi Pada Komunitas Perempuan Pesisir Mertasinga}

Pola komunikasi dibentuk dari hubungan dan fungsi komponen-komponen komunikasi dan dari suatu peristiwa komunikasi. Oleh karena itu, perlu dipahami terlebih dahulu komponen-komponen yang membantu peristiwa komuniksi di kalangan perempuan pesisir. Pembahasan tentang komponen komunikasi akan dipahami dengan baik apabila mengenal ciri-ciri umum perilaku komunikasi Perempuan pesisir. Berikut ciri-ciri umum tersebut:

Mereka berkomunikasi dengan cara-cara yang berbeda untuk partisipan 
Pola Komunikasi Perempuan Pesisir: Studi Etnografi Komunikasi yang berbeda. Di sini, ada dua model komunikasi ditemukan, yaitu komunikasi dengan orang luar dan komunikasi dengan orang dalam. Posisi dalam berkomunikasi tidak selalu sama, artinya kadang-kadang mereka berkomunikasi secara berhadapan, tetapi mereka juga sering beromunikasi sambil mengerjakan pekerjaan mereka, seperti sambil menyusui anak, sambil melayani penimbangan rajungan, sambil menyiangi jaring. Selalu dilakukan dalam ruang terbuka (di tempat pengepulan rajungan). Komunikasi dilakukan dalam jarak yang agak berjauhan. Komunikasi dilakukan dengan sedikit melakukan kontak mata. Overlap dalam aturan giliran percakapan. Komunikasi dikalangan perempuan pesisir tidak mengenal giliran berbicara, mereka secara spontan berbicara dan sering berebutan dan saling berlomba untuk menyatakan pendapat lebih dulu.

Penggunaan kalimat dalam komunikasi sangat sederhana. Memiliki banyak istilah sendiri (kosa kata yang khas) bagi mereka. Sangat dipengaruhi oleh aspek psikologis baik dari dalam diri pembicara maupun dari lawan bicara. Artinya, cara mereka menyampaikan pesan kepada lawan bicara terlihat sangat berapi-api, sehingga terlihat bagi orang luar seperti ngotot, atau seolah marahmarah.

Kurang menguasai bahasa Indonesia secara baik. Kurang menguasai bahasa daerah (jawa) halus. Intonasi dalam berbicara sangat cepat serta nada berbicaranya tinggi. Penggunaan kalimat yang sederhana dan bahasa jawa kasar ini merupakan salah satu ciri dari komunikasi di kalangan perempuan pesisir. Ciri lain adalah: kesederhanaan dalam penyampaian pesan, intonasi bicara yang cepat dan nada berbicara yang tinggi. Hal ini dipengaruhi oleh iklim / lingkungan fisik di kampung nelayan yang panas dan pekerjaan di laut yang bergelut dengan gemuruh suara ombak.

Setelah mengenal ciri-ciri umum perilaku komunikasi perempuan pesisir di atas, maka komponen-komponen komunikasi yang berperan besar dalam membentuk suatu peristiwa komunikasi meliputi: Setting, mencakup jarak ideal dalam berkomunikasi, aspek fisik lingkungan dan tempat terjadinya peristiwa komunikasi.Partisipan, mencakup orang yang menjadi lawan komunikasi. Artinya, siapa saja peserta yang terlibat dalam suatu peristiwa komunikasi di komunitas perempuan pesisir. Apakah peserta komunikasi menentukan cara mereka berkomunikasi. Khususnya, perbedaan antara in group dan out-group. Apakah usia dan status sosilal peserta komunikasi mempengaruhi mereka dalam komunikasi.

Bentuk pesan. Pesan apakah yang lebih dominan disampaikan dalam komunikasi perempuan pesisir. Apakah pesan berbentuk verbal lebih dominan dari pesan non verbal?. Tipe peristiwa, topik dan tujuan komunikasi. Perbedaan partispan komunikasi menyebabkan berbeda dalam tipe peristiwa komunikasi, Misalnya, Komunitas perempuan pesisir berkomunikasi secara serius kepada orang luar dan berkomunikasi secara santai (penuh candaan) kepada orang 
Yayah Nurhidayah

dalam. Begitu juga dengan topic dan tujuan komunikasi. Perbedaan partisipan menyebabkan perbedaan dalam topic dan tujuan komunikasi. Perempuan pesisir akan mengatur topic dan tujuan pembicaraan untuk partisipan yang berbeda. Ketika berbicara dengan orang dalam (komunitas perempuan pesisir) topic pembicaraan berkisar antara urusan-urusan pekerjaan di tempat pengepul ikan, masalah anak-anak dan keluarga.

Tujuan komunikasi mereka terutam adalah untuk melakukan transaksi, menjalin hubungan dan keakraban satu sama lain. Sedangkan ketika mereka berkomunikasi dengan orang luar, topic pembicaan berkenaan dengan urusanurusan publik, seperti: ekonomi, social, pendidikan, politik, budaya, agama dan lainnya. Tujuan komunikasi yang mereka lakukan tentu disesuaikan dengan topic yang dibahas, misalnya diskusi, tukar pendapat, seruan atau mungkin untuk mempengaruhi. Artinya, berbagai strategi komunikasi akan dilakukan oleh mereka seperti dilakukan masyarakat pada umumnya. Mereka bisa berkomunikasi secara serius, menggossip, bercandaan, diskusi dan problem solving.

Norma interpretasi: bagaimana perempuan pesisir memaknai setiap pesan yang disampaikan diantara mereka dalam peristiwa komunikasi. Mereka akan memaknai pesan sesuai dengan tingkat pengetahuan dan kemampuan yang mereka miliki. Adapun komponen-komponen lain, tidak memiliki porsi besar dan membedakan suatu peristiwa komunikasi. Dengan kata lain, komponenkomponen tersebut akan sama dalam setiap peristiwa komunikasi yang terjadi. Berikut adalah komponen komunikasi yang tidak besar pengaruhnya: Isi pesan, hal ini berhubungan dengan karakteristik bahasa komunitas perempuan pesisir. Artinya, dengan siapapun perempuan pesisir berkomunikasi mereka akan menggunakan bahasa yang sama. Urutan tindakan. Komponen ini sama, karena pada setiap peristiwa komunikasi melibatkan urutan tindakan yang sama. Yaitu overlap dalam pembicaraan. Kaidah interaksi mencakup hal-hal yang harus diperhatikan ketika perempuan pesisir berkomunikasi. Di komunitas perempuan pesisir ini hampir tidak ada batasan interaksi, tidak ada hierarki social yang membatasi interaksi. Mereka berinteraksi secara setara dengan suami, anak dan dengan juragan.

\section{Hubungan Antara Komponen-komponen dalam Peristiwa Komunikasi}

Untuk melihat bagaimana hubungan antara komponen-komponen yang membentuk perstiwa komunikasi pada komunitas perempuan pesisir, di sini penulis akan memaparkan beberapa kategori hubungan, antara lain: Menganalisis genre adalah menganalisis tentang tipe interaksi. Misalnya, mode interaksi yang bagaimana yang terjadi pada peristiwa komunikasi di komunitas perempuan pesisir, apakah menggunakan bentuk formal atau informal. Sedangkan menganalisis tentang topic pembicaraan adalah melihat tema-tema yang 
Pola Komunikasi Perempuan Pesisir: Studi Etnografi Komunikasi dibicarakan dalam peristiwa komunikasi di tempat pengepul ikan. Selanjutnya, akan dilihat apakah ada hubungan antara tipe peristiwa dengan topic yang dibicarakan?

Berdasarkan hasil pengamatan dan keterlibatan dalam interaksi dengan perempuan pesisir, diketahui bahwa tipe interaksi berhubungan dengan topic pembicaraan. Artinya, komunitas perempun pesisir hanya akan berbicara masalah pekerjaan di tempat itu saja, kepada teman-teman sesama penjual dan pengepul ikan saja. Di rumah mereka berkomunikasi dengan suami, mereka akan mengangkat topic pembicaraan yang berbeda, misalnya tentang anak-anak, tentang kebutuhan rumah tangga, tentang masa depan dan lain-lain. Sedangkan perempuan pesisir akan berbicara tentang topoik yang berbeda pula ketika berbicara kepada anak-anak mereka. Misalnya, tentang uang jajan, sekolah, tentang kasih sayang, tentang pendidikan dan lain-lain.

Tipe peristiwa komunikasi berhubungan dengan tujuan komunikasi. Berdasarkan pengamatan terhadap perilaku komunikasi perempun pesisir ditemukan bahwa komunikasi yang dilakukan di tempat kerja memiliki tujuan berbeda dengan komunikasi di rumah. Di tempat kerja tujuan komunikasi yang dilakukan oleh perempuan pesisir adalah untuk melakukan transaksi jual beli, menjalin hubungan, menunjukkan eksistensi diri dan status social, tetapi komunikasi yang dilakukan di rumah bersama anak-anak dan suami bertujuan menunjukan kasih sayang (afeksi), hiburan, kebersamaan, tugas dan harmoni. Jadi, tipe peristiwa komunikasi yang berbeda akan memiliki tujuan komunikasi yang berbeda pula. Dengan kata lain, tujuan komunikasi ditentukan oleh tipe peristiwa komunikasi yang terjadi.

Apakah ada hubungan antara genre (tipe peristiwa komunikasi) dengan topic dan setting (tempat terjadinya peristiwa komunikasi) ?. Sebagaimana telah dijelaskan di atas, bahwa tipe peristiwa komunikasi menentukan topic pembicaraan. Jika peristiwa komunikasi yang terjadi adalah komunikasi diantara anggota komunitas perempuan pesisir, maka topic pembicaan sekitar urusan pekerjaan dalam komunitas itu, sedangkan jika peristiwa komunikasi yang terjadi menyangkut hubungan antara suami- anak dan isteri, maka topic pembicaraan menyangkut urusan-urusan domestic saja.

Selain topic pembicaan menentukan dan ditentukan oleh tipe interaksi juga keduanya ditentukan oleh setting (tempat terjadinya interaksi). Berkomunikasi di tempat kerja memiliki pola komunikasi yang berbeda dengan pola komunikasi dalam keluarga. Jika diurutkan hubungan diantara ketiga komponen itu sebagai berikut: Setting menentukan tipe interaksi, dan tipe interaksi menentukan topic pembicaan.

Hubungan diantara komponen-komponen komunikasi di atas, dapat dijelaskan sebagai berikut: Pertama, genre (tipe peristiwa komunikasi) menentukan topic apa yang akan dibicarakan, sebaliknya topic apa yang akan 
Yayah Nurhidayah

dibicarakan dalam suatu peristiwa komunikasi ditentukan oleh setting (tempat terjadinya peristiwa komunikasi. Kedua, partispan komunikasi menentukan tipe peristiwa komunikasi, Misalnya, Komunitas perempuan pesisir berkomunikasi secara serius kepada orang luar dan berkomunikasi secara santai (penuh candaan) kepada orang dalam. Ketiga, Partisipan komunikasi menentukan bentuk pesan yang akan disampaikan. Sebagaimana yang terjadi dalam komunitas perempuan pesisir, mereka akan menggunakan bentuk komunikasi non-verbal lebih banyak kepada partisipan yang berjenis kelamin laki-laki, sebaliknya mereka lebih sering berkomunikasi verbal terhadap partisipan perempuan.

Dari beberapa paparan di atas, dapat disimpulkan bahwa ada beberapa komponen yang memiliki hubungan langsung seperti: setting, genre, topic, tujuan dan partisipan komunikasi. Namun, ada beberapa komponen yang tidak memiliki hubungan langsung seperti: Setting (tempat terjadinya peristiwa komunikasi) dengan bentuk pesan.

\section{Kompetensi Komunikasi Pada Komunitas Perempuan Pesisir}

Pembahasan tentang pola-pola komunikasi perempuan di kampung nelayan tidak akan lengkap bila tidak membahas tentang kompetensi komunikasi. Kompetensi komunikasi akan membantu masyarakat di luar komunitas berkomunikasi dengan komunitas nelayan. Secara teoritis, kompetensi komunikasi dapat dianalisis melalui tiga jenis keterampilan komunikasi: Pengetahuan linguistic (bahasa), keterampilan interaksi dan pengetahuan budaya.

Penelitian ini akan menyoroti kompetensi komunikasi di kalangan perempuan di kampung nelayan melalui dua jenis kompetensi saja yaitu: pengetahuan bahasa dan keterampilan interaksi. Hal-hal yang di analisis berkaitan dengan masalah tersebut meliputi: 1) Elemen-elemen bahasa verbal; 2) Pola elemen-elemen dalam peristiwa tutur tertentu; 3) Norma interaksi dan interpretasi; 4) Strategi komunikasi dan 5) Bentuk hubungan.

Elemen-elemen bahasa verbal dalam komunikasi di komunitas perempuan pesisir ini meliputi bahasa lisan dan bahasa tulisan. Bahasa lisan dipergunakan untuk menyampaikan pesan dan informasi diantara anggota komunitas dalam komunikasi berhadap-hadapan (face to face). Sedangkan bahasa tulis dipergunakan dalam aktifitas penjualan untuk mencatat berbagai keperluan pembukuan atau administrasi.

Unsur-unsur verbal berupa kata-kata yang disampaikan dalam interaksi sehari-hari perempuan di kampung nelayan dan bahasa non verbal berupa: symbol, isyarat, kontak mata, ekspresi wajah, sentuhan dan gerakan. Pola komunikasi perempuan pesisir ini secara dominan menggunakan pesan-pesan verbal berupa kata-kata. Namun, unsur non-verbalpun tidak bisa dihindari. Misalnya, kontak mata, sentuhan, ekspresi wajah dan gerakan-gerakan tubuh. Karena mereka berinteraksi secara intensif dalam waktu yang relative lama dari 
jam 9.00- 16.00 wib.

Berbagai perilaku komunikasi mereka tampilkan: ekspresi marah, ekpresi senang, ekspresi sedih, kontak mata satu sama lain, saling menyentuh bisa terjadi ketika mereka berolok-olok atau bercanda dan bersalaman serta melambaikan tangan ketika mereka akan berpisah dan membubarkan diri dari tempat kerja. Pesan-pesan non- verbal dan isyarat-isyarat lain yang dipergunakan diantara mereka tidak mengalami hambatan dalam pemaknaan, dimana satu sama lain mudah memahami pesan yang disampaikan. Kesamaan latar belakang dan karakteristik baik demografis, psikologis serta sosiologis inilah yang menjadi jembatan untuk mengurangi hambatan perbedaan dalam menafsirkan makna.

Dari hasil observasi ditemukan fakta bahwa keterbatasan penguasaan bahasa daerah (jawa) yang halus, menyebabkan pola komunikasi yang dilakukan oleh mereka tidak menggunakan variasi bahasa yang berbeda untuk orang yang berbeda. Penyampaian pesan verbal berupa kata-kata menggunakan bahasa jawa yang sehari-hari dipergunakan, baik untuk orang yang lebih muda, lebih tua maupun untuk orang yang status sosialnya lebih tinggi. Penghalusan bahasa itu hanya terdapat dalam cara-cara menyampaikan, dalam intonasi suara dan dalam nada berbicara. Kesederhanaan bahasa yang mereka pergunakan itu berlaku dalam semua situasi komunikasi. Di tempat pengepul ikan, di rumah, di acaraacara pengajian dan lainnya.

Setiap komunitas budaya memiliki kaidah dan aturan dalam berbicara. Siapa, mengatakan apa, kepada siapa, kapan dan dimana. Seorang komunikator akan menyampaikan pesan kepada khalayak menggunakan bahasa yang sesuai. Pesan disalurkan melalui saluran interpersonal maupun saluran komunikasi organisasi seperti: pertemuan formal dan menggunakan media (telepon). Peserta komunikasi dalam pertemuan-pertemuan di tempat pengepul ikan membuat beberapa kesepakatan, misalnya: siapa yang bertugas sebagai pengepul, penimbang, penyalur dan pemasok ikan. Mereka juga membuat aturan-aturan dalam penjualan mulai dari menentukan harga, prosedur penjualan, cara pembayaran dan lainya. Aturan-aturan yang telah disepakati itulah yang menjadi panduan atau norma dalam interaksi di kalangan mereka. Karenanya, jarang terjadi konflik dan persaingan.

Selain, aturan-aturan yang telah disepakati dalam kelompok, terdapat aturan-aturan umum yang berlaku di masyarakat. Di komunitas ini juga dikenal adanya norma-norma interaksi sebagai berikut: Menghormati yang lebih tua, misalnya dengan cara merendahkan nada suara dan tidak menyebut nama.

Selalu mengucapkan maaf, tolong dan terima kasih kepada orang lain. Selalu menyapa dan mengucapkan salam bila bertemu dengan orang yang lebih tua. Selalu menjaga hubungan dengan orang lain, sebisa mungkin menghindari pertengkaran.Berkaitan dengan strategi komunikasi atau cara untuk mencapai tujuan atau cara untuk menyampaikan maksud dalam komunikasi di kalangan 
perempuan pesisir sangat berkaitan dengan cara-cara mereka berkomunikasi antara lain: jujur, langsung, terbuka dan tidak ada niat jahat. Dari beberapa pengamatan ditemukan bahwa toleransi dan kerjasama diantara mereka itu sangat tinggi, misalnya di sela-sela kesibukannya mengasuh anak-anak, mereka saling membantu membersihkan jaring bapaknya dari sisa-sisa sampah yang masih menempel. Setelah selesai satu pekerjaan mereka bisa membantu membersihkan jaring milik orang lain, tanpa mengharap imbalan.

Keterbatasan dalam penguasaan bahasa Indonesia di kalangan perempuan pesisir Mertasinga, membuat mereka tidak terbiasa menggunakan bahasa Indonesia sebagai alat komunikasi pada umumnya. Keterampilan komunikasi yang mereka miliki hanya terbatas pada bahasa jawa yang menjadi bahasa seharihari mereka dalam komunitas itu. Penguasaan bahasa Indonesia secara baik, hanya dimiliki oleh sebagian masyarakat yang berpendidikan. Oleh karena itu, pola komunikasi di kalangan perempuan pesisir cenderung tidak berbeda untuk partisipan yang berbeda.

Keterampilan dalam berinteraksi di kalangan perempuan pesisir umumnya tidak mengalami hambatan. Mereka sudah terbiasa berinteraksi dengan masyarakat luar, yang memiliki sifat dan karakter yang berbeda. Dalam berinteraksi dengan masyarakat di luar komunitas mereka, biasanya perempuan pesisir memiliki strategi sendiri, mereka kerap menggunakan norma-norma interaksi yang berlaku secara umum. Sebagaimana telah disebutkan di atas. Selain itu, prinsip kejujuran, apa adanya, keterbukaan, langsung dan tidak memiliki niat jahat menjadi keyakinan yang kuat dalam cara-cara mereka berinteraksi dengan orang dari kalangan manapun.

Dari beberapa penjelasan di atas, dapat disimpulkan bahwa berkomunikasi dengan masyarakat pesisir, terutama komunitas perempuan desa Mertasinga diperlukan pengertian dan pemahaman terhadap berbagai budaya dan cara-cara mereka berinteraksi dan berkomunikasi. Ada beberapa strategi atau persyaratan yang harus dipenuhi antara lain: Memahami istilah yang dibuat atau disepakati bersama oleh komunitas perempuan pesisir. Memahami bahasa yang mereka pergunakan, menunjukkan sikap antusias dalam berkomunikasi dengan mereka tidak memperlihatkan diri sebagai orang yang memiliki status lebih tinggi dari mereka, berusaha dengan segala cara mengerti apa yang mereka sampaikan, dan jangan pernah menyepelekan atau menganggap mereka bodoh atau tidak mampu melakukan sesuatu.

\section{PENUTUP}

Berdasarkan hasil penelitian yang telah dilakukan, maka penelitian tentang pola komunikasi komunitas perempuan pesisir dapat disimpulkan: Peristiwa Komunikasi. Komunitas perempuan pesisir dalam berkomunikasi menggunakan dua bentuk pesan: verbal dan non-verbal. Komunikasi verbal dilakukan 
Pola Komunikasi Perempuan Pesisir: Studi Etnografi Komunikasi umumnya ketika mereka berkomunikasi dengan sesama perempuan. Sedangkan komunikasi non-verbal dilakukan lebih sering ketika mereka berkomunikasi dengan laki-laki. Dua bentuk pesan ini menjadi indikator utama terjadinya peristiwa komunikasi yang khas di kalangan perempuan pesisir.

Komponen-komponen komunikasi yang terdiri dari: situasi komunikasi, peserta komunikasi, tujuan komunikasi, topic pembicaraan, tindakan komunikasi, model intraksi, saluran komunikasi, norma interaksi dan genre (tipe peristiwa). Dari sepuluh komponen komunikasi tersebut, hanya beberapa komponen yang memiliki pengaruh besar dalam membentuk peristiwa komunikasi pada komunitas perempuan pesisir antara lain: situasi komunikasi, peserta komunikasi, bentuk pesan, kaidah interaksi, dan tipe peristiwa. Komponen-komponen ini akan berubah sesuai dengan partisipan yang dihadapi dan setting tempat peristiwa komunikasi itu terjadi. Sedangkan komponen-komponen yang lain seperti: topik, tipe dan tujuan komunikasi, urutan tindakan, dan isi pesan komunikasi. Dikatakan tidak memiliki pegaruh besar dalam membentuk peristiwa komunikasi. Karena tidak menimbulkan perbedaan besar dalam dua peristiwa komunikasi yang ada. Dari beberapa paparan di atas, dapat disimpulkan bahwa ada beberapa komponen yang memiliki hubungan langsung seperti: setting, genre, topic, tujuan dan partisipan komunikasi. Namun, ada beberapa komponen yang tidak memiliki hubungan langsung seperti: Setting (tempat terjadinya peristiwa komunikasi) dengan bentuk pesan.

Berdasarkan hubungan antara komponen-komponen komunikasi, dapat disimpulkan bahwa pola komunikasi perempuan pesisir dapat dibedakan pada dua pola komunikasi yaitu pola komunikasi dengan orang dalam (in-group) dan pola komunikasi dengan orang luar (out group). Dari pola komunikasi dengan orang dalam dapat diturunkan menjadi: pola komunikasi di tempat kerja dan pola komunikasi dalam keluarga.

Keterbatasan dalam penguasaan bahasa Indonesia di kalangan perempuan pesisir Mertasinga, membuat mereka tidak terbiasa menggunakan bahasa Indonesia sebagai alat komunikasi pada umumnya. Keterampilan komunikasi yang mereka miliki hanya terbatas pada bahasa jawa yang menjadi bahasa seharihari mereka dalam komunitas itu. Penguasaan bahasa Indonesia secara baik, hanya dimiliki oleh sebagain masyarakat yang berpendidikan. Oleh karena itu, pola komunikasi di kalangan perempuan pesisir cenderung tidak berbeda untuk partisipan yang berbeda.

Keterampilan dalam berinteraksi di kalangan perempuan pesisir umumnya tidak mengalami hambatan. Mereka sudah terbiasa berinteraksi dengan masyarakat luar, yang memiliki sifat dan karakter yang berbeda. Dalam berinteraksi dengan masyarakat di luar komunitas mereka, biasanya perempuan pesisir memiliki strategi sendiri, mereka kerap menggunakan norma-norma interaksi yang berlaku secara umum. Selain itu, prinsip kejujuran, apa adanya, 
Yayah Nurhidayah

keterbukaan, langsung dan tidak memiliki niat jahat menjadi keyakinan yang kuat dalam cara-cara mereka berinteraksi dengan orang dari kalangan manapun.

Penelitian tentang "Pola Komunikasi pada komunitas perempuan pesisir" ini merupakan penelitian yang pertama dilakukan, ditambah lagi dengan waktu penelitian yang sangat singkat untuk model penelitian etnografi komunikasi, maka hasil penelitian belum bisa menggambarkan pola komunikasi yang ada secara detail. Oleh karena itu, penulis perlu menyampaikan bebagai saran, antara lain:

Penelitian ke depan perlu dilakukan secara lebih komprehensif, tidak hanya membatasi diri pada pola komunikasi komunitas perempuan nelayan, tetapi juga melakukan penelitian terhadap berbagai aspek budaya yang ada di kampung nelayan yang mempengaruhi pandangan hidup dan perilaku komunikasi mereka.

Penelitian menggunakan metode etnografi komunikasi perlu dilanjutkan, karena model penelitian ini masih sangat langka dalam tradisi penelitian di IAIN Sykeh Nurjati Cirebon, terutama pada bidang keilmuan komunikasi dan penyiaran Islam (KPI). Penelitian tentang pola komunikasi pada masyarakat tutur dalam komunitas lain, masih perlu dilanjutkan. Hal ini penting, dalam rangka memperoleh pengertian bersama dalam masyarakat.

\section{DAFTAR PUSTAKA}

Amanah, S. (2010). Peran Komunikasi Pembangunan dalam Pemberdayaan Masyarakat Pesisir. Jurnal Komunikasi Pembangunan, 8(1).

Deviani, E. (2013). Analisis Kesiapsiagaan dan Kerentanan Perempuan di Wilayah Pesisir dalam Menghadapi Bencana Gempa dan Tsunami di Banda Aceh. Idea Nursing Journal, 4(3).

Dharma, R. (2016). Pengaruh Kepemimpinan, Komunikasi dan Lingkungan Kerjaterhadap Kinerja Pegawai Kantor Dinas Pendidikan dan Kebudayaan Kabupaten Pesisir Selatan . Ekobistek Upi "Yptk" Padang, 5(2).

Fajar, A. (2011). Analisis Interaksi Simbolik yang Membentuk Pola Komunikasi

Dinamis Pada Komunitas Pesisir Kabupaten Jember. Jurnal Sosial Ekonomi Pertanian, 5(2).

Fatimah, J. M. (2016). Family Communication Strategy to Improve Gender Equality for Girls in Coastal of South Sulawesi Province (Strategi Komunikasi Keluarga untuk Meningkatkan Kesetaraan Gender bagi Anak Perempuan di Kawasan Pesisir Provinsi Sulawesi Selatan). Jurnal Pekommas, 1(2).

Fithria dkk. (2012). Partisipasi Perempuan Nelayan dalam Konservasi Wilayah

Pesisir di Kecamatan Meureubo Kabupaten Aceh Barat. Jurnal Manajemen Sumberdaya Lahan, 1(1).

Handayani. (2011). Kajian Perempuan Pesisir dalam Mendukung Konservasi 
Sumber Daya Pesisir di Kabupaten Raja Ampat. Jurnal Akuatika, 2(1).

Mulyadi, A. (2011). Perempuan Madura Pesisir Meretas Budaya Mode Produksi Patriarkat. Jurnal Karsa, 19(2).

Mulyana, Dedy, 2003. Komunikasi Masyarakat Kontemporer. Bandung: PT. Remaja Rosda Karya.

Nengsih dkk. (2013). Bantuan PNPM Mandiri dalam Bidang Simpan Pinjam

Bagi Perempuan Di Nagari Sungai Liku Kecamatan Ranah Pesisir

Kabupaten Pesisir Selatan. Pendidikan Geografi, 2(1).

Ningsih dkk. (2014). Fataloza Nur Razak : Profil Perempuan Penerima Bantuan

Program Nasional Pemberdayaan Masyarakat (Pnpm) Mandiri di Nagari

Lalang Panjang Kecamatan Air Pura Kabupaten Pesisir Selatan.

Pendidikan Sejarah, 3(2).

Parwati, T. 2014). Hubungan Komunikasi Interpersonal Remaja Putri Bersama

Orang Tua Dengan Perilaku Seks (Studi terhadap Remaja Putri di Nagari

Lunang Satu Kecamatan Lunang Kabupaten Pesisir Selatan). Bimbingan dan Konseling. 1(1).

Riza dkk. (2016). Komunikasi Antarpribadi Warga Belajar Di Pkbm Sari

Kecamatan Rumbai Pesisir Kota Pekanbaru. Jurnal Online Mahasiswa (JOM) Bidang Keguruan dan Ilmu Pendidikan, 3(2).

Ruata dkk. (2014). Intensitas Komunikasi Pembelajaran dalam Mengukur

Keberhasilan Program Pendidikan Paket B di Desa-Desa Pesisir

Kecamatan Belang. Kareba : Jurnal Ilmu Komunikasi, 3(1).

Saraswati, R. (2012). Tugas dan Wewenang Badan Pemberdayaan Masyarakat,

Perempuan dan Keluarga Berencana (BPMPKB) dalam Meningkatkan

Kesejahteraan Nelayan di Wilayah Pesisir Kota Tegal. Diponegoro Law Review, 1(4).

Sefridanita dkk. (2012). Kategori dan Fungsi Sosial Ungkapan Kepercayaan

Masyarakat Larang Pantang Calon Pengantin Perempuan di Nagari Barung-Barung Balantai Kecamatan Koto Xi Tarusan Kabupaten Pesisir Selatan. Bahasa dan Sastra, 1(1).

Trisnani. (2016). Society Communication Patterns In The Era Of Information

Technology Case Study Coastal Village, Besuki District, District Situbondo. Jurnal Penelitian Komunikasi dan Opini Publik, 20(1).

Wahyudi, A. (2011). Peran Emansipatoris Perempuan Pesisir (Istri Nelayan Sebagai Ujung Tombak Ekonomi). Jurnal Karsa, 19(2). 